\title{
Determinant factors of fishermen income and decision-making for providing welfare insurance: An application of multinomial logistic regression
}

\author{
Sukono $^{a^{*}}$, Riaman ${ }^{a}$, Titin Herawati ${ }^{a}$, Jumadil Saputra ${ }^{\mathrm{c}}$ and Endang Soeryana Hasbullah ${ }^{\mathrm{a}}$
}

${ }^{a}$ Department of Mathematics, Faculty of Mathematics and Natural Sciences, Universitas Padjadjaraan, Indonesia

${ }^{b}$ Faculty of Fisheries and Marine Science, Universitas Padjadjaran, Indonesia

${ }^{c}$ Faculty of Business, Economics and Social Development, Universiti Malaysia Terengganu, 21030 Kuala Nerus, Terengganu, Malaysia

\section{H R O N I C L E}

Article history:

Received October 28, 2020

Received in revised format:

October 29, 2020

Accepted November 172020

Available online

November 17, 2020

Keywords:

Decision-making

Fishermen income

Fishermen welfare

Multinomial logistic regression

\begin{abstract}
A B S T R A C T
As a country surrounded by the ocean, Indonesia is categorized as a country that has marine potential. The fishermen communities' economy depends on ocean. However, the fishermen communities live below the poverty line and their average income is less than regional minimum wage. In conjunction with the issue, this study seeks to investigate the factors affecting the income of fishermen communities and right decision to fishermen in covering with welfare insurance in Cirebon, Indonesia. The quantitative study is designed using cross-sectional approach. The data collected by applying random sampling with open-ended questions and interview. A total of 100 fishermen's have participated in this study. The study used some factors in measuring the fishermen community income, namely coastal environment condition, fish catching technology and location, operational capital, climate (season) condition, fishermen's age, fishermen's education, and fishing experience. The data are analyzed using the multinomial logistic regression model by assisting the statistical software, i.e., SPSS-23. The results show that coastal environment condition, fish catching technology and location, operational capital, climate (season) condition, fishermen's age, fishermen's education, and fishing experience have significant effects on fishermen income. Interestingly, the factor of coastal environment condition and climate (season) condition have significant negative effects on fishermen income. In conclusion, this study identified that two important factors reduced the welfare level of fishermen (via income). Also, in line with that things, the right decision which can provide to support and assist the fishermen community was by providing the welfare insurance. It is purposely to give them the protection from various risks faced by fishermen.
\end{abstract}

\section{Introduction}

Indonesia is a country which has been surrounded by ocean and it has become a country with considerable marine potential. It will be making the fishermen communities' life prosperous since their livelihood comes from the ocean. Unfortunately, the fisher communities' lives are often identical to the poverty (Noer, 2018; Rinaldi et al., 2019; Pranata, 2019). The recent level of fishermen's prosperity is still under the agrarian sector. Fishermen (especially for traditional fishermen) are grouped into the most improvised social group level over other groups in the agrarian sector (Purcell et al., 2016; Ghani et al., 2017; Firdaus, 2020; Prawiti \& Dewi, 2020).

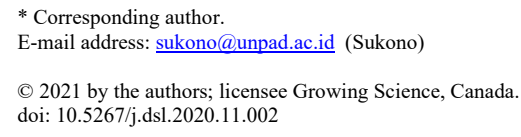


As a consequence, the use of marine and coastal resources optimally will support the growth of local economy and gives high advantage to fishermen communities' prosperity (Adili \& Antonia, 2017; Fatihudin, 2019). Still, seas and coastal areas are not the main priorities for the national economy growth and it is unable to give prosperity to communities. Hence, most of fishermen communities are still below the poverty line (King et al., 2018; Imam et al., 2018; Jönsson, 2019; Ernayani et al., 2020). Most of communities in coastal areas in Indonesia are fishermen from generation to generation. Their characteristics are dynamically constructed as surrounding resources, so they should keep moving from one location to others to get the optimal fish capture (Seara et al., 2016). Besides, the high business risk makes fishermen communities live in the stern natural athmosphere which is always in uncertainties in carrying out their business (Primyastanto, 2015; Biswal et al., 2017; Leasiwal, 2017; Rusmana et al., 2019; Putri \& Wulandari, 2020; Lein \& Setiawina, 2018).

Communities who work and earn money from as fishermen are the ones who do business activities through getting income from fishing. Fishermen are people who actively do their job in capturing fishes (Himes-Cornell \& Kasperski, 2016). The prosperity level of fishermen is extremely determined by fish capture results. The quantity of fish capture reflects their income and this income is mostly used for family necessities (Huchim-Lara et al., 2016; Sutton \& Rudd, 2016; Hoang et al., 2020). According to Salim (1999), factors affecting fishermen's income involve: capital, number of ships, number of employees, fishing mileage, and experiences. Henceforth, it is needed to investigate the factors affecting fishermen's income to learn which factors significantly affect fish capture results.

Several researchers have focused on identifying factors affecting fishermen's income, by involving some variables and methods. A study by Rinaldi et al. (2019) investigated the factors affecting fishermen's income in Sibolga City. They used some variables, namely asset ownerships, education levels, work hours, and work experiences. The research population were fishermen who used outboard motorboats under 5GT type with the fishing tool of net sticks. The data were collected using purposive sampling technique toward 90 fishermen through the open-ended questionnaire. The data were analyzed using the Cobb-Douglas production function. The result of their study found that the asset ownerships, education levels, work hours, and work experiences had significant effects on fishermen's income in Sibolga.

Further, Putri and Wulandari (2020) studied whether or not the fishermen's experiences, educations, and work hours influence the fishermen's income. The population were fishermen distributed from two regencies, namely Central Bangka and East Belitung with a total of 238 respondents. The study used the primary data and collected using the interview and self-administered questionnaire. The data were analyzed using a qualitative approach through path analysis. The result of their study showed that fishermen's experiences and work hours significantly affect the fisher's income while their education was insignificant.

Leasiwal (2017) investigated the fishermen communities' income condition in West Rurehe and West Serum Districts. He aimed to study whether the fishing experiences, education levels, fishing labor wages, and technologies affect fishermen's income level. The data were obtained through questionnaire and interview. The data were analyzed using qualitative descriptive and quantitative using panel data regression. The result reflected that factors of fishing experiences, fishing labor wages, and technologies absolutely affect the increase of fishermen's income while education levels do not.

In addition, Ridha (2017) carried out a study in coastal area of Idi Rayeuk District, aiming to identify whether or not the variable of capital, employees, experiences, fish prices, and fish catching numbers affect the fishermen's income. A total of 30 fishermen of outboard motorboats were collected by using the random sampling technique. The study was designed using quantitative approach and analyzed using multiple linear regression model. The result showed that only the variable of capital, fish prices, and fish capture numbers that partially effect on fishermen's income. Such studies have also been conducted by Depledge et al. (2017), Satumanatpan and Pollnac (2017), and Young et al. (2019). By the following previous elaboration, the current study tries to fulfill the gaps from previous studies by considering the factors that affect the fishermen income and right decision to fishermen in covering with welfare insurance in Cirebon, Indonesia.

\section{Materials and Methods}

This section presents the materials and methods used in this study. The materials explain about the object of the data and factors to be analyzed while the methods deal with models used in the study.

\subsection{Material}

The data were fishermen communities who earned money from capturing fishes in the area of Cirebon Indonesia. The data consisted of 100 samples, from the open sampling method through questionnaire and interview. From 100 respondents, the fishermen's income generally was differentiated into two categories, including $n_{1}=20$ or $20 \%$ respondents as category 1 who got the high income, and $n_{0}=80$ or $80 \%$ respondents as category 0 , who get the medium to low incomes. Factors expectantly affecting the fishermen's income were 8 (eight) variables, including Coastal environment condition $\left(X_{1}\right)$, Fish capture technology $\left(X_{2}\right)$, Fish capture location $\left(X_{3}\right)$, Operational capital $\left(X_{4}\right)$, Climate (season) condition $\left(X_{5}\right)$, Fishermen's 
age $\left(X_{6}\right)$, Fishermen's education $\left(X_{7}\right)$, and Fishing experience $\left(X_{8}\right)$. To the data, which will require normality test, as discussed below.

\subsubsection{Definition of operational variables}

Fishermen's income is the value received by fishermen from selling fish capture results as measured in the rupiah unit. Fishermen communities' income is dependent to the use of fishery resource potentials in the sea.

Coastal environment degradation is reflected by what happens to mangrove forests. It does not merely affect land shifting and shrinking but threatens the living life. The population of some kinds of fish potentially keeps decreasing due to the damage and disappearance of habitat.

Catching fish activities use traditional or modern fishing tool. Fish capture with a traditional technology will result in fewer number of capture result compared to the modern one.

Fish catching location is an area compatible for the fish habitat, naturally, known as the fish capture area. The condition needed for this area is that this area is possibly compatible for fish life and habitat and has a great amount of fish food.

Capital is included into the production factor. If there is no capital, fishermen have no ability to pay the operational fee or pay and buy tools they use. The amount of the operational cost affects the fishermen's total income. It is due to that the operational cost increases fish capture numbers.

Season considerably affects the fishermen's lives in the monsoon west and monsoon east seasons. The high wave due to the monsoon west and east will decrease the fishermen's income.

Age: people reaching the age of 15 and above are included to fishermen while the ones below the age of 15 are not, although they participate in fishing. People at the age of 15 is considered to be responsible to fulfill the fish capture target, so the income also increases.

Education, before becoming fishermen, they usually get or do not get formal educations such as elementary school, junior high school, senior high school.

Experience, a person is considered as a fisherman if he has reached the age from 15 to 30 , a person above the age of 30 is considered as an experienced fisherman (pawing). It is also a category or classification to determine the fish capture number.

Further, we employ the normality test whereas the independent variable for the data value is fluctuated. The strong difference between data values affects bias in the analysis so that it would not reflect the real situation. The normality test was conducted using the statistical software of SPSS 23. After conducting the normality test, the data were used in the estimation analysis of logistic regression model (Sidi et al., 2017.b; 2018; Sukono et al., 2018.a; Taslim et al., 2020.a; 2020.b).

\subsection{Method}

\subsubsection{Logistic regression model}

The logistic regression was a part of the regression model analysis often used to estimate probabilities of an event by matching the data in the logit function of logistic curves. This method was a general linear model used in the binomial regression. As in the general regression model, this method used some predictor variables in terms of numeric and category (Sukono et al., 2014; Sidi et al., 2018).

\subsubsection{Multinomial Logistic Regression Model}

In conducting the data analysis in which the response variable was nominal, the study used a method developed from the logistic regression model, namely the nominal logistic regression model while the response variable in terms of ordinal used the ordinal logistic regression model (Sukono et al., 2014; Sidi et al., 2017.b). Multinomial logistic regression model (nominal and ordinal) is an approach used to describe the relationship between some predictor variables $X$ and a multinomial response variable (polytomous). The nominal logistic regression model is used when there is no order between the response categories analyzed. One category is selected to be a reference category. The multinomial logistic regression model is generally represented in the following equation. 


$$
P(Y=j \mid x)=\pi_{j}(x)=\frac{\left.\exp \mid g_{j}(x)\right]}{\sum_{k=0}^{r-1} \exp \left[g_{k}(x)\right]}=\frac{\exp \left(\beta_{j 0}+\beta_{j 1} x_{2}+\beta_{j 2} x_{2}+\ldots+\beta_{j p} x_{p}\right)}{\sum_{k=0}^{r-1} \exp \left(\beta_{k 0}+\beta_{k 1} x_{2}+\beta_{k 2} x_{2}+\ldots+\beta_{k p} x_{p}\right)},
$$

where $P(Y=j \mid x)$ : the conditional probability from the response variable $\mathrm{Y}$ for the $j$ category on the vector $x, j=0,1, \ldots, r-1 ; \pi_{j}(x):$ the logistic regression model for the response variable $\mathrm{Y}$ for the $j$ category; $g_{j}(x):$ the model logit for the $j$ category; $x_{m}$ : the value of the $m$ explanatory, $m=1,2,3, \ldots, p ; \beta_{j m}$ : the coefficient parameter estimators. Where, the vector $\widetilde{\beta}_{0}=0$, so $g_{0}(x)=0 ; \widetilde{\beta}_{0}$ : the parameter coefficient of logit model for the response variable $\mathrm{Y}$ to the 0 category $\left(\beta_{00}, \beta_{01}, \ldots, \beta_{0 p}\right)$ (Sukono et al., 2014; Sidi et al., 2018).

For the response variable with $r$ category, it is able to form $r$-1 equation of the logit model, where each equation forms the binary logistic regression consisting of a group of category toward reference, as shown in the following equation.

$$
g_{r-1}(x)=\ln \frac{P(Y=r-1 \mid x)}{P(Y=0 \mid x)}=\ln \left(\frac{\pi_{r-1}(x)}{\pi_{0}(x)}\right)=\beta_{(r-1) 0}+\beta_{(r-1) 1} x_{1}+\ldots+\beta_{(r-1) p^{x}} .
$$

In general, the steps conducted in the multinomial logistic regression model analysis include: (1) estimating parameter coefficients for the multinomial logistic regression; (2) conducting tests on parameter coefficients to simultaneously know the compatibility multinomial logistic regression model estimators; (3) conducting tests on parameter coefficients to partially know predictor variables mostly affecting the multinomial logistic regression model; (4) conducting the interpretation on the ratio of trend value based on multinomial logistic regression model estimators (Sukono et al., 2014; Sidi et al., 2017.b).

\subsubsection{Coefficient parameter estimator}

In the coefficient parameter estimators of logistic regression model, the expected values between response variables are not linear and have not similar variation so the coefficient parameter estimator $\widetilde{\beta}$ can be obtained through the Maximum Likelihood Estimation. The function of conditional Likelihood for the data sample as many as $n$ observation is stated as the following,

$$
l(B)=\prod_{i=1}^{n}\left[\pi_{0}\left(x_{i}\right)^{y_{0 i}} \pi_{1}\left(x_{i}\right)^{y_{1 i}} \pi_{2}\left(x_{i}\right)^{y_{2 i}} \ldots \pi_{r-1}\left(x_{i}\right)^{y_{(r-1) i}}\right] .
$$

If the left and right sides of Eq. (3) are taken the natural algorithm, the log Likelihood function it is obtained as follows,

$$
\begin{aligned}
& L(\beta)=\ln [l(\beta)] \\
& L(\beta)=\ln \left[\prod_{i=1}^{n}\left[\pi_{0}\left(x_{i}\right)^{y_{0 i}} \pi_{1}\left(x_{i}\right)^{y_{1 i}} \pi_{2}\left(x_{i}\right)^{y_{2 i}} \ldots \pi_{r-1}\left(x_{i}\right)^{y_{(r-1) i}}\right]\right] .
\end{aligned}
$$

To get the $\widetilde{\beta}$ estimator value that is able to maximize into $L(\beta)$, we need to the first and second derivatives respect to function $L(\beta)$. $\beta$ value can be determined using the Newton- Rapson iteration method (Sukono et al., 2017.a; 2017.b; Sirait et al., 2020).

\subsubsection{Testing parameter}

Testing parameter simultaneously; Testing coefficient parameters was simultaneously conducted to test the role of predictor variables in multinomial logistic regression model estimators simultaneously toward the response variable. Testing the hypotheses were reflected in the followings.

$H_{0:}: \beta_{j 1}=\beta_{j 2}=\ldots=\beta_{j p}=0$, means that there is no influence of predictor variables toward the response variable.

$H_{1}$ : there is minimally one $\beta_{j m} \neq 0$, which means there is at least one predictor variable affecting the response variable, $m=1,2, \ldots p$, with the testing statistic as represented below, 


$$
G=-2 \ln \left[\frac{l_{0}}{l_{k}}\right] .
$$

$H_{0}$ will be rejected in $\alpha$ the significance level if the statistic value of $G>X^{2}{ }_{(v ; a)}$ or $p-v a l u e<\alpha$. If $H_{0}$ is rejected, the predictor variables simultaneously or wholly affect the response variable (Sukono et al., 2018.b; 2019.c).

Testing parameter individually; Testing coefficient parameters was partially conducted to individually test each role of predictor variables in the model. Testing variables was conducted after using the Wald statistics. The hypotheses used were in the followings,

$H_{0}: \beta_{j m}=0$, indicates that there is no influence of the $m$ predictor variable toward the variable response of the $j$ category.

$H_{1}: \beta_{j m} \neq 0$, indicates that there is influence of the $m$ predictor variable toward the variable response of the $j$ category.

$j=0,1,2, \ldots r-1 ; \quad m=1,2, \ldots, p$

The statistic of Wald test is as follows,

$$
W=\left[\frac{\hat{\beta}_{j m}}{\operatorname{Se}\left(\hat{\beta}_{j m}\right)}\right]^{2}
$$

A hypothesis of $H_{0}$ is rejected if the statistic $W>X_{(1 ; \alpha)}^{2}$ or $p-$ value $<\alpha$. If a hypothesis of $H_{0}$ is rejected, the coefficient parameter estimator of $\beta_{j m}$ significantly affects the response variable (Sukono et al., 2014; 2019.b). Hosmer and Lameshow test is known as a test of logistic regression models fit to the data. Statistic test of Hosmer \& Lemeshow is follows,

$$
\hat{C}=\sum_{k=1}^{g} \frac{\left(O_{k}-n_{k} \bar{\pi}_{k}\right)}{n_{k} \bar{\pi}_{k}\left(1-\bar{\pi}_{k}\right)} \text { or } P_{-} \text {Value }=\operatorname{Pr}(\hat{C})
$$

where $O_{k}=\sum_{j=1}^{n_{k}} Y_{j}$ and $\bar{\pi}_{k}=\sum_{j=1}^{n_{k}}\left(m_{j} \bar{\pi}_{j} / n_{k}\right)$.

The hypotheses are as follows:

$H_{0}$ :There is no difference between the results of observations with the model used;

$H_{l}$ :There is a difference between the results of observations with the model used.

Hosmer \& Lemeshow follow the Chi-Square distribution with degrees of freedom $d f=(g-2)$, with a general $g=10$.

Test criteria used were: Rejecting a hypothesis of $H_{0}$ if statistic value $\hat{C}>\chi_{(1-\alpha)(g)}^{2}$, otherwise accepting hypothesis of $H_{0}$ when $\hat{C} \leq \chi_{(1-\alpha)(g)}^{2}$ where $\alpha$ the significance level is established (Sukono et al., 2014; 2019.a).

$\boldsymbol{R}$-Square; Hosmer and Lemeshow, the determination value of $R^{2}$ in logistic regression model analysis showed strong relationships between independence variables and dependence variables. Statistic of $R^{2}$ can be determined using the formula as follow:

$$
R^{2}=1-\exp \left[-\left(\frac{L^{2}}{N}\right)\right],
$$

where $L$ is the value of the $\log$ likelihood of the model, and $N$ is the number of data. If the determination value of $R^{2} \rightarrow 1$, then the relationship between the independent variable and the independent variable is strong. Conversely, if the determination value of $R^{2} \rightarrow 0$, then relationship is weak (Sukono et al., 2014; Sidi et al., 2017.a).

\section{Results}


The data were analyzed as described in section 2.1. For multivariate analysis, before the data is used to further analysis normality test is necessary. The purpose of normality test in multivariate analysis is to know whether distribution of the data (following or close to) is normally distributed. Normality test of data is performed using SPSS version 23 . Once the data are normally distributed, then this data is used to estimate parameters of binary logistic models. The coefficient parameter estimators of the binary logistic regression is conducted to determine vector of $\hat{\boldsymbol{\beta}}=\left(\hat{\beta}_{0}, \hat{\beta}_{1}, \ldots, \hat{\beta}_{8}\right)$ coefficient, which can maximize log probability function in the Eq. (4). The estimation is carried out using SPPS software version 17.0. The result of parameter estimates, and standard error values of each parameter estimate are represented in Table 1.

There is a need to conduct a test for the significance to coefficient parameter estimators in which predictor variables relatively affect the response variable of $\pi(X)$. The null hypothesis testing used is $H_{0}: \hat{\beta}_{0}=\hat{\beta}_{1}=\ldots=\hat{\beta}_{8}=0$ against the alternative hypothesis $H_{1}: \exists \hat{\beta}_{0} \neq \hat{\beta}_{1} \neq \ldots \neq \hat{\beta}_{k} \neq 0 \quad(k=0,1, \ldots, 8)$. Testing the significance is simultaneously carried out using statistic of Log Likelihood $G$ test referring to Eq. (5). The calculation uses SPSS software version 23 and results in the statistic value of Log Likelihood ratio yields $\hat{G}=-27.01226348994915$. It is clear that the statistic $\hat{G}$ asymptotically distribute chi-squares $\left(\chi^{2}\right)$ with eight degrees of freedom, i.e. $d f=8$. When the significant level is determined $\alpha=0.05$, from the table of chi-square is obtained $\chi_{(1-0.05)(8)}^{2}=2.7326$. Since the statistic value of $\hat{G}>\chi_{(1-0.05)(8)}^{2}$, then the hypothesis $H_{0}$ is rejected, it indicates that $\hat{\boldsymbol{\beta}}=\left(\hat{\beta}_{0}, \hat{\beta}_{1}, \ldots, \hat{\beta}_{8}\right)$ coefficient is significant to simultaneously affect the response variable $\pi(X)$.

The $\hat{Z}$ statistic is asymptotically normal distributed, so if the significance level is determined $\alpha=0.05$, the $\hat{Z}$ statistic are obtained $Z_{\frac{1}{2}(0.05)}=-0.27$ and $Z_{\frac{1}{2}(1-0.05)}=0.27$. While the $\hat{Z}$ statistic is in the interval $-0.27 \leq \hat{Z} \leq 0.27$, then the hypothesis $H_{0}$ is accepted, else the hypothesis $H_{0}$ is rejected.

Table 1

Coefficient Parameter and Standard Error Estimators

\begin{tabular}{lcccc}
\hline \multicolumn{1}{c}{$\begin{array}{c}\text { Coefficient Parameter of Variables } \\
\left(X_{i}\right)\end{array}$} & $\begin{array}{c}\text { Estimator of } \\
\text { Parameter } \\
\left(\hat{\beta}_{i}\right)\end{array}$ & $\begin{array}{c}\text { Standard } \\
\text { Error } \\
S E\left(\hat{\beta}_{i}\right)\end{array}$ & $\begin{array}{c}\text { Ratio }(\hat{Z}) \\
\hat{\beta}_{i}\end{array}$ & $\begin{array}{c}\text { Significance } \\
S E\left(\hat{\beta}_{i}\right)\end{array}$ \\
\hline Constant & -1.9807175 & 0.635 & $-3,11924016$ & Significance \\
Coastal environment condition $\left(X_{1}\right)$ & -1.05250123 & 1.067 & -0.98641165 & Significance \\
Fish capture technology $\left(X_{2}\right)$ & 2.05312435 & 1.978 & 1.03797995 & Significance \\
Fish capture location $\left(X_{3}\right)$ & 0.76586961 & 0.617 & 1.24279757 & Significance \\
Operational capital $\left(X_{4}\right)$ & 0.92524281 & 0.574 & 1.61192127 & Significance \\
Climate (season) condition $\left(X_{5}\right)$ & -2.12394297 & 3.205 & -0.66269672 & Significance \\
Fishermen's age $\left(X_{6}\right)$ & 0.44294572 & 0.382 & 1.15954377 & Significance \\
Fishermen's education $\left(X_{7}\right)$ & 0.08972099 & 0.072 & 1.24612486 & Significance \\
\hline Fishing experience $\left(X_{8}\right)$ & 0.74122571 & 2.541 & 0.29211220 & Significance \\
\hline
\end{tabular}

Log Likelihood Statistic $=-27.01226348994915$

Based on the $\hat{Z}$ statistics in Table 1, all coefficient parameter estimators are significant. It indicates that coeficient parameter estimators affect fishermen's income. After conducting log Likelihood ratio and Wald tests, Hosmer \& Lemeshow test is carried out. Hosmer \& Lemeshow test is to analyze the compatibility of logistic regression model estimators with the real data. The hypotheses of Hosmer \& Lemeshow are the follows.

$H_{0}$ :There is no difference between the observations with the estimators of the model.

$H_{1}$ : There is a difference between the observations with the model estimators.

Testing Hosmer \& Lemeshow statistic is conducted using the Eq. (7). Test can also be performed using the statistical of $P_{-}$Value, the test criteria is rejected $H_{0}$ if $P_{-}$Value is less than the significance level of $\alpha$. In this test, $P_{-}$Value is 0.293 . If the significance level is determined as $\alpha=0.05$, then obviously $P_{-}$Value is greater than the significance level of $\alpha$. Therefore, the hypothesis $H_{0}$ is accepted, which means "there is no difference between the observations with the logistic regression model estimator". 
Next step, to measure how strong the relation between predictor and response variables can be determined by the coefficient of determination $R^{2}$. The coefficient of determination $R^{2}$ is calculated using the Eq. (8). The result indicates the coefficient of determination $R^{2}=0.99957323$, obtained from the logistic regression model estimators, portraying that the relationship between predictor variables: Coastal environment condition $\left(X_{1}\right)$, Fish capture technology $\left(X_{2}\right)$, Fish capture location $\left(X_{3}\right)$, Operational capital $\left(X_{4}\right)$, Climate (season) condition $\left(X_{5}\right)$, Fishermen's age $\left(X_{6}\right)$, Fishermen education $\left(X_{7}\right)$, and Fishing experience $\left(X_{8}\right)$, with the response variable of $\pi(X)$ is very strong.

Consequently, based on the result of coefficient parameter estimators given in the Table 1 with referring to Eq. (2), the logistic regression model estimators are stated in the following equation.

$$
\begin{aligned}
& \hat{g}_{r-1}(x)=\ln \left(\frac{\pi_{r-1}(x)}{\pi_{0}(x)}\right)= \\
& -1.9807175-1.05250123 X_{1}+2.05312435 X_{2}+0.76586961 X_{3}+0.92524281 X_{4} \\
& -2.12394297 X_{5}+0.44294572 X_{6}+0.08972099 X_{7}+0.74122571 X_{8} .
\end{aligned}
$$

Based on the Eq. (9), the discussion section is described in the followings.

\section{Discussion}

Considering the analysis result presented in Table 1, the eight factors (variables) analyzed both simultaneously and partially are significant in affecting the response variable (fishermen communities' income). There are six factors positively affecting the income, including Fish capture technology $\left(X_{2}=2.05312435\right)$, Fish capture location $\left(X_{3}=0.76586961\right.$, Operational capital $\left(X_{4}=0.92524281\right.$, Fishermen's age $\left(X_{6}=0.44294572\right)$, Fisherman's Education $\left(X_{7}=0.08972099\right.$, and Fishing experience $\left(X_{8}=0.74122571\right)$. One of these factors, fish capture technology factor, has the highest coefficient parameter estimator with the value of 2.05312435. It shows that this factor has the highest influence on the fishermen's income. When this factor is increased, it will significantly increase the fishermen's income. Still, the influences of other factors also need to be considered. The coefficient parameter estimator of education is equal 0.08972099 which is considered as the lowest one. It implies that it has a little influence on the increase of fishermen's income, especially traditional fishermen (Srikanthan, 2013; Squires \& Wiber, 2018).

Meanwhile, there are two factors negatively affect the income: Coastal environment condition $X_{l}=-1.05250123$ and Climate (season) condition $\left(X_{5}\right)=-2.12394297$. These negative influence show that the increase of a unit of estimator will decrease the income. The climate (season) condition factor has the highest coefficient parameter estimator ( -2.12394297$)$, indicating that the more the climate (season) condition makes the high wave, the fewer the fishermen are able to go fishing, so they lose their incomes. Another negative factor is coastal environment condition with coefficient parameter estimator of $(-1.05250123)$ which reflects that the more the environment degradation condition, the more the fish habitat gets damaged (i.e. the damage of coral reefs, abrasion, sedimentation, and so forth), so fishes will move out from one location to another. This condition results in the decrease (disappearance) of fish colonies (Udbye, 2014; Yang, 2017; Sambuo et al., 2018).

Indonesia is an archipelago country surrounding by seas reaching 5.8 million kilometer and become a country with the biggest marine area in the world, with the coastal line of 95.181 kilometer. The natural resource potentials containing in Indonesian marine territory should have given the prosperity to Indonesian people, especially coastal communities. In the irony, the poverty of coastal communities remains high with poverty headcount index (PHI) of $32.4 \%$. This number is obtained from the general image of fishermen communities' income in the coastal area of Gebang District, Cirebon Regency with the average income per day between IDR. 75,000 - 150,000 or IDR. 1,000,000-3,000,000 in a month. The minimum Regency Wage (UMK) in Cirebon in 2020 is IDR. 2,196,416. Therefore, there are many fishermen with monthly income under the UMK. Indeed, there are many factors obstructing fishermen communities' prosperity, and investigation is needed (Noer, 2018; Firdaus, 2020). Regarding the Protection and Empowerment of Fish Cultivator and Salt Farmer, a program of Insurance Premium Assistance for Fishermen (BPAN) has been implemented. It becomes one of the government's priority programs through Ministry of Marine Affairs and Fisheries (KKP), that is also in line with Nawacita number five, namely increasing Indonesian human life quality. BPAN aims to guarantee the better fishermen activities in fish capturing so the fishermen's rights and responsibilities become clear and their fish capture activities will be protected. The advantages include fishermen's peace and comfort and the increase of fishermen's awareness to continue using the insurance individually (Supriatna et al., 2018; Sidi et al., 2019). Evidently, the result of investigating factors affecting fishermen communities' income is necessary for the information supply chain for the government and related institutions, so the insurance programs for fishermen can be carried out effectively and efficiently. This could happen by applying supply chain management principles, the information cycle and policy products, starting from the condition happening in fishermen communities to the government, marine authorities, and insurance enterprises. This can be re-used by fishermen communities and managed in the integrated way (Chase et al., 2007; Valverde, 2014; Njegomir \& Rihter, 2017). 


\section{Conclusion}

This paper concluded that there are eight factors investigated on affecting fishermen's income, particularly fishermen communities in the area of Cirebon Indonesia. Th eight factors analyzed both simultaneously and partially are significant to fishermen's income. The logistic regression model estimators used in this analysis yields the coefficient of determination $R^{2}=0.99957323$, indicating that the relationship between predictor variables (factors) and the response variable (fishermen's income) is extremely strong, so the logistic regression model is reasonable to be used in this investigation. Eight factors identified are certainly useful for the government and related institutions as the information supply chain in relation to insurance risk management for fishermen communities, particularly those who live in the coastal areas, Cirebon Indonesia.

\section{Acknowledgements}

We would like to thank for Director of General of Higher Education of the Republic of Indonesia (Dikti), and Chancellor, Director of the Directorate of Research, Community Engagement, and Innovation (DRPMI), and the Dean of the Faculty of Mathematics and Natural Sciences (FMIPA), Universitas Padjadjaran (Unpad), who have provided the Basic Research Scheme Grant with Contract Number: 1827/UN6.3.1/LT/2020. Also, we would also like to thank to Universiti Malaysia Terengganu (UMT) for supporting this research collaboration and publication.

\section{References}

Adili, Z. Y., \& Antonia, M. (2017). Determinants influencing fishing income to the coastal households of Indian Ocean. Oceanography \& Fisheries, 4(3), 1-7. https://doi.org/10.19080/OFOAJ.2017.04.555640

Biswal, R., Johnson, D., \& Berkes, F. (2017). Social wellbeing and commons management failure in a small-scale bag net fishery in Gujarat, India. International Journal of the Commons, 11(2), 684-707. http://doi.org/10.18352/ijc.742

Chase, R. B., Aquilano, N. J., \& Jacobs, F. R. (2007). Operations management for competitive advantage (11th ed.). McGraw-Hill/Irwin.

Depledge, M., Lovell, R., Wheeler, B., Morrissey, K., White, M., \& Fleming, L. (2017). Future of the sea: Health and wellbeing of coastal communities. Foresight - Future of the Sea Evidence Review, Government Office for Science.

Ernayani, R., Herianingrum, S., Widiastuti, T., Harianto, R. P., \& Zainal, M. I. (2020). Factors influencing income smoothing practice in the oil and natural gas mining companies during 2012-2016 period. Humanities \& Social Sciences Reviews, 8(1), 359-365. https://doi.org/10.18510/hssr.2020.8146

Fatihudin, D. (2019). Globalization, strengthening of Indonesian local market character as consequences and reality of open economic system. Humanities \& Social Sciences Reviews, 7(3), 11-16. https://doi.org/10.18510/hssr.2019.732

Firdaus, A. M. (2020). Ekonomi Desak Nelayan Tetap Melaut Meski Gelombang Tinggi. AyoCirebon.com. https://www.ayocirebon.com/read/2020/07/29/6070/ekonomi-desak-nelayan-tetap-melaut-meski-gelombang-tinggi

Ghani, N. A., Raub, M. A., Adam, F., Abdullah, B., Eusoff, Y. A., \& Puteh, D. A. H. M. A. (2017). Quality of Life (QoL) of fishermen in the west coast states of Peninsular Malaysia. International Journal of Academic Research in Business and Social Sciences, 7(4), 313-330. http://dx.doi.org/10.6007/IJARBSS/v7-i4/2808

Himes-Cornell, A., \& Kasperski, S. (2016). Using socioeconomic and fisheries involvement indices to understand Alaska fishing community well-being. Coastal Management, 44(1), 36-70. https://doi.org/10.1080/08920753.2016.1116671

Hoang, H. H., Vu, T. B., Ho, H. V., Vu, H. T., \& Nguyen, Q. D. (2020). Factors affecting offshore fishing households' income in southern central coast of Vietnam. Management Science Letters, 10(6), $1369-1376$. https://doi.org/10.5267/j.ms1.2019.11.020

Huchim-Lara, O., Salas, S., Fraga, J., Méndez-Domínguez, N., \& Chin, W. (2016). Fishermen's perceptions and attitudes toward risk diving and management issues in small-scale fisheries. American Journal of Human Ecology, 5(1), 1-10. https://doi.org/10.11634/216796221605760

Imam, Md. F., Islam, M. A., \& Hossain, M. J. (2018). Factors affecting poverty in rural Bangladesh: An analysis using multilevel modelling. Journal of Bangladesh Agriculture University, 16(1), $123-130$. https://doi.org/10.3329/jbau.v16i1.36493

Jönsson, J. H. (2019). Overfishing, social problems, and ecosocial sustainability in Senegalese fishing communities. Journal of Community Practice, 27(3-4), 213-230. https://doi.org/10.1080/10705422.2019.1660290

King, T., Abernethy, K., Brumby, S., Hatherell, T., Kilpatrick, S., Munksgaard, K., \& Turner, R. (2018). Sustainable fishing families: Developing industry human capital through health, wellbeing, safety and resilience. Report to the Fisheries Research and Development Corporation Project No. 2016/400. Deakin University, Western District Health Service, University of Tasmania and University of Exeter. Canberra, October. CC BY 3.0.

https://www.frdc.com.au/Archived-Reports/FRDC Projects/2016-400-DLD.pdf

Leasiwal, T. C. (2017). Determinants of fishermen income in Regency of West Seram, Maluku (Study in 3 Village of West Seram Regency). Cita Ekonomika, 11(1), 11-17. https://doi.org/10.31227/osf.io/cdg8w

Lein, A. A. R., \& Setiawina, N. D. (2018). Factors affecting the fishermen household income and welfare. International Research Journal of Management, IT \& Social Sciences, 5(4), 80-90. https://doi.org/10.21744/irjmis.v5n4.266 
Njegomir, V., \& Rihter, J. D. (2017). The role and importance of insurance of business and supply chain interruptions. Management:Journal of Sustainable Business and Management Solutions In Emerging Economies, 20(77), 53-60. https://doi.org/10.7595/management.fon.2015.0025

Noer, N. M. (2018). Sosial Ekonomi Masyarakat Pesisir. Kompasiana.

https:/www.kompasiana.com/nawawimnoer/5ab89b56dd0fa868be7e2612/sosial-ekonomi-masyarakat-pesisir

Pranata, N. (2019). Financial inclusion in Indonesia's fishery sector: Factors determining credit participation. Institutions and Economies, 11(4), 51-77.

Prawiti, I. G. A. I., \& Dewi, M. H. U. (2020). Analysis of impact factors on fishermen income in the Lovina Beach, Buleleng District. American Journal of Humanities and Social Sciences Research, 4(3), 171-176.

Primyastanto, M. (2015). Economic analysis of Pandega fishermen household at Madura strait to keep food security. International Journal of Oceans and Oceanography, 9(2), 97-104.

Putri, A. K., \& Wulandari, A. (2020). Factors influencing the income of fishermen. Integrated Journal of Business and Economics, 4(2), 198-210. http://dx.doi.org/10.33019/ijbe.v4i2.298

Purcell, S. W., Ngaluafe, P., Foale, S. J., Cocks, N., Cullis, B. R., \& Lalavanua, W. (2016). Multiple factors affect socioeconomics and wellbeing of artisanal sea cucumber fishers. PLoS ONE, 11(12), e0165633. https://doi.org/10.1371/journal.pone.0165633

Ridha, A. (2017). Analisis Faktor-Faktor yang Mempengaruhi Pendapatan Nelayan di Kecamatan Idi Rayeuk. Jurnal Samudra Ekonomi Dan Bisnis, 8(1), 646-652. https://doi.org/10.33059/jseb.v8i1.205

Rinaldi, M., Harahap, A., Nugrahadi, E. W., \& Hutasuhut, S. (2019). Factors affecting fishers' income in Sibolga City. Advances in Social Sciences Research Journal, 6(7), 359-370. https://doi.org/10.14738/assrj.67.6770

Rusmana, E. M., Anna, Z., Nurruhwati, I., \& Nurhayati, A. (2019). Role of fishermen's wives in family decision making (Case study in Karangsong Village, Indramayu Subdistrict, Indramayu Regency, West Java). Global Sciences Journal, 7(5), 419-430.

Samah, A. A., Shaffril, H. A. M., Hamzah, A., \& Samah, B. A. (2019). Factors affecting small-scale fishermen's adaptation toward the impacts of climate change: Reflections from Malaysian fishers. SAGE Open, 1-11. https://doi.org/10.1177/2158244019864204

Sambuo, D., Kirama, S., \& Malamsha, K. (2018). Fish price determination around lake Victoria, Tanzania: Analysis of factors affecting fish landing price. Global Business Review, 1-16. https://doi.org/10.1177/0972150917811509

Satumanatpan, S., \& Pollnac, R. (2017). Factors influencing the well-being of small-scale fishers in the Gulf of Thailand. Ocean \& Coastal Management, 142(15), 37-48. https://doi.org/10.1016/j.ocecoaman.2017.03.023

Seara, T., Pollnac, R. B., \& Poggie, J. J. (2016). Changes in job satisfaction through time in two major New England fishing ports. Journal of Happiness Studies, 18, 1625-1640. http://dx.doi.org/10.1007/s10902-016-9790-5

Sidi, P., Mamat, M., Sukono, \& Supian, S. (2017.a). Evaluation model for risk insurance premiums of building damage caused by flood: Case study in Citarum watershed, Southern Bandung, Indonesia. Journal of Engineering and Applied Sciences, 12(17), 4420-4425.

https://doi.org/10.3923/jeasci.2017.4420.4425

Sidi, P., Mamat, M., Sukono, \& Supian, S. (2017.b). Supply and demand analysis for flood insurance by using logistic regression model: Case study at Citarum watershed in South Bandung, West Java, Indonesia. IOP Conf. Series: Materials Science and Engineering, 166, 012002. https://doi.org/10.1088/1757-899X/166/1/012002

Sidi, P., Mamat, M. B., Sukono, Supian, S., \& Putra, A. S. (2018). Demand analysis of flood insurance by using logistic regression model and genetic algorithm. IOP Conf. Series: Materials Science and Engineering, 332, 012053. https://doi.org/10.1088/1757-899X/332/1/012053

Sidi, P., Santoso, A., Mamat, M., Sukono, Subiyanto, \& Bon, A. T. (2019). Measuring the level of ability to pay flood insurance premiums and the factors that influence it by using the contingent valuation method. Proceedings of the International Conference on Industrial Engineering and Operations Management, Riyadh, Saudi Arabia, November 2628, 2019, 372-381.

Sirait, H., Sukono, Sundari, S., \& Kalfin. (2020). Ratio estimator of population mean using quartile and skewness coefficient. International Journal of Advanced Science and Technology, 29(6), 3289-3295.

Squires, K., \& Wiber, M. G. (2018). Distribution of fishery benefits and community well-being: A review of increased access to the Eastern Nova Scotia snow crab fishery. Ecology and Society, 23(2), 25(1-12). https://doi.org/10.5751/ES$10137-230225$

Srikanthan, S. (2013). Impact of climate change on the fishermen's livelihood development: A case study of village in Coromandel Coast. IOSR Journal of Humanities and Social Science, 12(6), 49-54. https://doi.org/10.9790/08371264954

Sudarmo, A. P., Baskoro, M. S., Wiryawan, B., Wiyono, E. S., \& Monintja, D. R. (2015). Social economics characteristics of coastal small-scale fisheries in Tegal City, Indonesia. International Journal Of Scientific \& Technology Research, $4(1), 85-88$.

Sukono, Sholahuddin, A., Mamat, M., \& Prafidya, K. (2014). Credit scoring for cooperative of financial services using logistic regression estimated by genetic algorithm. Applied Mathematical Sciences, 8(1), 45-57. http://dx.doi.org/10.12988/ams.2014.310600 
Sukono, Nahar, J., Putri, F. T., Subiyanto, Mamat, M., \& Supian, S. (2017.a). Estimation of outstanding claims reserving based on inflation risk on car insurance companies by using the bootstrap method. Far East Journal of Mathematical Sciences, 102(4), 687-706. https://doi.org/10.17654/MS102040687

Sukono, Suyudi, M., Islamiyati, F., \& Supian, S. (2017.b). Estimation model of life insurance claims risk for cancer patients by using Bayesian method. IOP Conf. Series: Materials Science and Engineering, 166, 012022. https://doi.org/10.1088/1757-899X/166/1/012022

Sukono, Aisah, I., Tampubolon, Y. R. H., Napitupulu, H., Supian, S., Subiyanto, \& Sidi, P. (2018.a). Estimated value of insurance premium due to Citarum River flood by using Bayesian method. IOP Conf. Series: Materials Science and Engineering, 332, 012047. https://doi.org/10.1088/1757-899X/332/1/012047

Sukono, Riaman, Lesmana, E., Wulandari, R., Napitupulu, H., \& Supian, S. (2018.b). Model estimation of claim risk and premium for motor vehicle insurance by using Bayesian method. IOP Conf. Series: Materials Science and Engineering, 300, 012027. https://doi.org/10.1088/1757-899X/300/1/012027

Sukono, Hasbullah, E. S., Kartiwa. A., Hidayat, Y., Subiyanto, \& Bon, A. T. (2019.a). Reinsurance loss model at individual risk for short term in life insurance. Proceedings of the International Conference on Industrial Engineering and Operations Management, Bangkok, Thailand, March 5-7, 2019, 2118-2129.

Sukono, Lesmana, E., Hasbullah, E. S., Rosario, V., Hidayat, Y., \& Subiyanto. (2019.b). Determination of optimal insurance company reimbursement by using exponential utility functions. IOP Conf. Series: Materials Science and Engineering, 567, 012038. https://doi.org/10.1088/1757-899X/567/1/012038

Sukono, Rusyaman, E., Saputra, J., Ekanurnia, D., \& Hidayat, Y. (2019.c). Supply chain strategy for managing risk for health insurance: An application of Bayesian model. International Journal of Supply Chain Management, 8(4), 884893.

Supriatna, A., Parmikanti, K., Novita, L., Sukono, Subartini, B., \& Bon, A. T. (2018). Calculation of net annual health insurance premium using Burr distribution. Proceedings of the International Conference on Industrial Engineering and Operations Management, Paris, France, July 26-27, 2018, 2954-2962.

Sutton, A. M., \& Rudd, M. A. (2016). Factors influencing community fishers' leadership engagement in international smallscale fisheries. Frontiers in Marine Science, 3(116), 1-17. https://doi.org/10.3389/fmars.2016.00116

Taslim, D., Darana, S., Setiyadi, W., \& Sukono. (2020.a). Analysis of business efficiency and profit factors of local broiler duck using Cobb-Douglas production function. International Journal of Advanced Science and Technology, 29(5), 256265.

Taslim, D., Darana, S., Setiyadi, W., Sukono, \& Kalfin. (2020.b). Financial analysis and business sensitivity on duck livestock in Bandung District, West Java Province. International Journal of Advanced Science and Technology, 29(8), $1065-1071$.

Udbye, A. (2014). Supply chain risk management in India: An empirical study of sourcing and operations disruptions, their frequency, severity, mitigation disruptions, mitigation methods, and expectations methods, and expectation (Publication No. Paper 1813) [Doctoral dissertation: Portland State University]. PDXScholar.

Valverde, R. (2014). A supply chain financial management insurance model for the protection of corporations against the bankruptcy of suppliers by using the Black-Scholes-Merton model (Publication No. 280560660) [Master dissertation: The University of West of England]. ResearchGate.

Yang, D. (2017). An impact analysis of small-scale fisheries Community-Based Fisheries Management (CBFM) in Asia: A Meta-Analysis (Publication No. 1483) [Doctoral dissertation: University of Connecticut]. Uconn Library.

Young, T., Fuller, E. C., Provost, M. M., Coleman, K. E., Martin, K. St., McCay, B. J., \& Pinsky, M. L. (2019). Adaptation strategies of coastal fishing communities as species shift poleward. ICES Journal of Marine Science, 76(1), 93-103. https://doi.org/10.1093/icesjms/fsy140

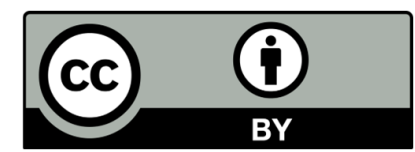

(C) 2021 by the authors; licensee Growing Science, Canada. This is an open access article distributed under the terms and conditions of the Creative Commons Attribution (CC-BY) license (http://creativecommons.org/licenses/by/4.0/). 